\title{
PENGARUH KUALITAS PRODUK DAN PROMOSI TERHADAP KEPUTUSAN PEMBELIAN PRODUK PRISTINE 8+ PADA PT SUPER WAHANA TEHNO
}

\author{
Ahmad Maulana Irfanudin ${ }^{1)}$, Ratih Andalusi, Ismail Jamil \\ Staf Pengajar FE UNPAM \\ 1) dosen unpam,email : dosen01868@unpam.ac.id, dosen01868@unpam.ac.id
}

\begin{abstract}
ABSTRAK
Penelitian ini bertujuan untuk mengetaui ada atau tidaknya pengaruh Kualitas Produk, dan Promosi terhadap Keputusan Pembelian produk air minum Pristine 8+ scra bersama-sama, guna mengetahui adanya pengaruh KualitasProduk, Promosi terhadap KeputusanPembelian produk air minum Pristine 8+ scara à, serta untuk mengetahui variabel mana yang paling mempengaruhi Keputusan pembelian air minum Pristine 8+. Dalam penelitian ini, digunakan variabel bebas yakni kualitasProduk $\left(\mathrm{X}_{1}\right)$, Promosi $\left(\mathrm{X}_{2}\right)$. Metode analysis yang di gunakan adalah analysis regresii liniier berganda. Dimana Sample dalam penelitian ini sejumlah 113 peserta survey yang terdiri atas customer GeneralTrade di Jabodetabek yang membeli produk air minum pristine scra brkala di Super Wahana Tehno, PT. Menggunakan teknik sesnsus atau dengan kata lain sampel jenuh. Data yang di pergunakan adalah data-primer yang adalahhasil jwaban respondence trhadap angket yang di bagikan. Berdasar hasil uji hipotesis secara partial antara Variabel KualitasProduk $\left(\mathrm{X}_{1}\right)$ terhadap KeputusanPembelian $(\mathrm{Y})$ sebesar 32,4\% yang berarti pengaruh positif dan signifikan. Dari pengujian hipotesis menunjukkan $t_{\text {hitung }}>\mathbf{t}_{\text {Table }}$ $(2,337>1,659)$. Yang berarti $\mathrm{H}_{\mathrm{o}}$ ditolak dan $\mathrm{H}_{1}$ diterima. Berdasar hasil uji hipotesis secara partial antara Variabel Promosi $\left(\mathrm{X}_{2}\right)$ terhadap KeputusanPembelian $(\mathrm{Y})$ sebesar 30,4\% yang artinya pengaruh positif dan signifikan. Dari pengujian hipotesis menunjukkan $\mathfrak{t}_{\text {hitung }}>\mathbf{t}_{\text {Table }}$ $(4,876>1,659)$. Makaa $\mathrm{H}_{\mathrm{o}}$ ditolak dan $\mathrm{H}_{1}$ diterima. Dari pengujian $\mathrm{F}$ (simultan) menunjukkan $\mathrm{F}_{\text {hitung }}>\mathrm{F}_{\text {Table }}(21,355>2,81)$ berarti bahwa Ho ditolak dan Ha diterima. Dalam uji $\mathrm{R}$ kuadrat atau koef determin. terdapat pengaruh $54 \%$ dari variabel kualitasProduk,Promosi terhadap keputusanPembelian. Sementara presentasse sisa dijelaskan variable diluar analisiis regresi tersebut.
\end{abstract}

Kata kunci: kualitas produk, promosi, dan keputusan pembelian

\section{ABSTRACT}

The research aims to determines the presence of the influence of Product Quality, and Promotion of the Decision of Purchasing Pristine 8+ drinking water products simultaneously, to determine the effect of Product Quality, and Promotion of the Decision of Purchasing Pristine 8+ drinking water products partially, and to determine the variables which one influences the decision to purchase Pristine $8+$ drinking water. On thhis research, independ variables which is product quality $\left(X_{1}\right)$ and Promotion $\left(X_{2}\right)$ are used. The analytical method used is multiple linear regression analysis. The sample used in this study was 113 respondents consisting of potential GT (General Trade) clients in Jabotabek who made regularly purchases of pristine drinking water products at PT Super Wahana Tehno. Where all members of the population are taken or can be called Saturated Sampling. The data obtained are primary data which is the result of respondents' answers to the questionnaire distributed. Based on the calculation results of partial hypothesis testing between Product Quality Variables $\left(X_{1}\right)$ to the Buying Decision $(Y)$ of $32.4 \%$ there is a positive and significant effect. From testing the hypothesis shows $t$-count $>$ t-table $(2.333>1.659)$. Which means $H o$ was rejected and $H_{1}$ accepted. Based on the calculation results of partial hypothesis testing between the Promotion Variable $\left(\mathrm{X}_{2}\right)$ to the Purchasing Decision $(Y)$ of $30.4 \%$ there is a positive and significant effect. 
From testing the hypothesis shows t-count> t-table (4,876> 1,659). Which means Ho was rejected and $\mathrm{H} 1$ accepted. From the F test (simultaneous) shows Fcount> Ftable (21,355> 2.81) means that Ho is rejected and Ha is accepted. In the determination test there is an effect of $54.5 \%$ of the independent variables (product quality and Promotion) on the dependent variable (purchasing decisions). The remaining $45.5 \%$ is explained by other variables and is not included in this regression analysis.

Keywords: quality of product, promotion and buying decision.

\section{PENDAhUluAN}

\section{A. Latar Belakang}

Pertumbuhan bisnis yang makin maju di masa ini menuntut perusahaan atau pelaku usaha untuk dihadapkan pada persaingan yang demikian ketat. Akses pelayanan yang serba cepat membuat kebutuhan pelanggan me-nuntut unttuk lebih di perhatikkan, terlebih dalam pelayanan.

Perusahaan yang berorientasi pada hasil produksi khususnya produk-produk yang dikonsumsi pelanggan sehari-harinya memiliki keyakinan bahwa pelanggan atau calon pelanggan akan membeli products dengan kualitas yang lebiih unggul jika dicompare dengan products serupa yang beredar dipasaran.

Melihat dari rupa setiap air mineral tidaklah berbeda, tapi jika mengetahui lebih dalam, dibalik rasa tawar air mineral, ternyata memiliki kadar kandungan yang menentukan besar kualitas air tersebut.
Potensial Hidrogen (pH) adalah indikator pengukur tingkat derajat asam atau basa setiap cairan atau larutan, termasuk air. Menggunakan $\mathrm{pH}$, kita dapat mengetahui secara pasti tiap cairan, apakah ia cenderung asam atau basa, dimana $\mathrm{pH}$ ditunjukkan dengan satu satuan angka. Batasan satuan potensial hidrogen antara satu sampai dengan empat belas, dimana titik air atau cairan dikatakan netral jika posisi angka potensial hidrogen berada di angka tujuh (7). Semakin rendah angka $\mathrm{pH}$ dari larutan atau cairan, maka cairan atau larutan tersebut makin bersifat asam. Dengan kata lain, semakin tinggi angka $\mathrm{pH}$ larutan atau cairan, dapat dikatakan semakin larutan atau cairan tersebut bersifat basa.

Lalu bagaimanakah seharusnya air minum yang ideal utuk dikonsumsi seharihari? Jika berpatokan pada nilai netral air atau larutan atau cairan di angka $\mathrm{pH}=7$, maka larutan atau air ideal untuk dikonsumsi berkisar pada nilai $\mathrm{pH}$ tersebut. Beberapa air mineral juga dikatakan 
sebagai air mineral dengan $\mathrm{pH}$ tinggi, yang bermanfaat bagi tubuh manusia.

Air mineral ayng memiliki kandungan $\mathrm{pH}$ tinggi, tidak hanya bersifat basa, tapi memiliki rasa yang cendderung lebih pahit, hal ini mencerminkan manfaat yang diberikan pada tubuh manusia.

Dilakukan beberapa riset terkait dengan mengkonsumsi air minum dengan kandungan $\mathrm{pH}$ tinggi, di rentang 8 s.d. 9 bermanfaat untuk mnurunkan asam lambung krna sifatnya yang basa. Selain itu air dengan $\mathrm{pH}$ tinggi dapat meningkatkan kekuatan tulang karena kandungan bi-karbonat dan calcium tinggi yang terkandung didalamya.

Keputusan pembelian adalah serangkaian decision making processes seorang pelanggan dalam melakukan kegiatan pembelian produk atau jasa, yaitu hasil kolaburasi pengetahuan dan pengalaman untk menentukan dua atau lbih altrnatif produks yang trsedia yang di pengaruhi atas bberapa factor, diantaranya quality, price location, promotion, service dan sebagainya.

Pengambillan kputusan oleh seorang pelanggan dalam membeli suatu produk atau jasa, di mulai dengan awareness atau kesadaran atas kebutuhan ayng meseti dipenuhi serta menyadari masalah selanjutnya, lalu pelanggan akan melakukan langkah-langkah hinggal sampai pada evaluasi after sales.

Kotler (2011) mengatakan, keputusan pembelian yaitu suatu aktifitas seorang pelanggan memilih mau atau tidaknya ia untuk mengkonsumsi próduk atau jasá. Dari beberapa faktor - faktor yang mndorong pleanggan untuk membeli produk atau jasa, biasanya konsumen atau pelanggan akan menimbang setiap kwalitas, harga dan produk yang familier ditengah masyarakat.

Berdasarkan pada penjelasan diatas, serta melihat peluang dan tantangan bisnis yang dihadapi perusahaaan, peneliti mengambil tema penelitian dengan judul "Pengaruh Kualitas Produk dan Promosi Terhadap Keputusan Pembelian Produk Pristine 8+ (Studi Kasus PT Super Wahana Tehno)".

\section{B. Rumusan Masalah.}

Didasari atas penjelasan pada latar belakang mendetail sebelumnya, peneliti me rumuskan point permasaalahan sebagai berikut:

1. Seberapa besar dampak KualitasProduk air minum Pristine 
trhadap KeputusanPembelian Produk

Air Minum Pristine?

2. Seberapa besar dampak Promosi trhadap Keputusan Pembelian Air Minum Pristine?

3. Seberapa beesar dampak KualitasProduk dan Promosi teerhadap KeputusanPembelian Produk Air Minum Pristine secara bersama-sama?

\section{Tujuan Penelitian}

Setelah dibuat perumusan masalah dan analisa yang dijabarkan pada latar belakang diatas, tujuan dilakukan penelitian ini yakni untuk :

1. Menguji serta meng-analisis

KualitasProduk berpengaruh trhadap KeputusanPembelian pada PT Super Wahana Tehno.

2. Menguji dan menganalisis Promosi berpengaruh terhadap Keputusan Pembelian pada PT Super Wahana Tehno.

3. Menguji dan menganalisis KualitasProduk dan Promosi berpengaruh secara brsama-sama teerhadap KeputusanPembelian pada PT Super Wahana Tehno.

\section{TINJAUAN PUSTAKA}

\section{A. Manajemen Pemasaran}

Pengurusan pemasaran adalah proses merancang dan melaksanakan pemikiran, harga, promosi, dan menyalurkan ide, barangan dan perkhidmatan untuk mewujudkan pertukaran yang memenuhi matlamat individu dan organisasi. (Philip Kotler, 2002: 9) .

Kotler dan Armstrong dalam bukunya Principles of Marketing (2006) mendefinisikan pengurusan pemasaran sebagai seni dan sains memilih pasaran sasaran dan membina hubungan yang saling menguntungkan dengan pasaranpasaran ini .

Definisi lain mengatakan bahawa pengurusan pemasaran adalah aktiviti menganalisis, merancang untuk melaksanakan, dan mengawasi semua aktiviti (program), untuk mendapatkan tahap pertukaran yang baik dengan pembeli sasaran untuk mencapai matlamat organisasi. (Buchari Alma, 2007: 130) .

\section{B. Product Quality}

Product quality atau Kualitas produk Kotler dan Armstrong (2009) mengatakan bahwa Produk adalah sgala sesuatu ayng dapat di tawarkan ke market untuk mendapatkan prhatian, acquisition, pengguunaan atau konsumsii, sehingga memuaskan keinginan atau kebutuhan pelanggan. Sedangkan Page | 106 
Kualitas Produk didefinisikan sebagai kemampuan sebuah produk utk melakukan kegunaannya atau fungsinya. Kegunaannya itu diantaranya adalah meliputi durability, reliability, ketelitian kasil, kemudahan operasional dan perbaikan, serta atribbutatribut lainnya yg berharga dari produk tersebut scra keseluruhan.

\section{Promosi}

Promosi yakni suatu aktifitas penyampaian informasii dari perusahaaan kpada kustomer atau pihak lain dalam channel penjualan untuk membentuk sikap dan tingkah laku terkait dengan konsumsi suatu produk atau jasa.

Menurut Baker (2000), Melalui promosi pengiklanan syarikat mengarahkan komunikasi yang persuasif untuk menargetkan pembeli dan orang ramai melalui media yang dipanggil media massa seperti surat khabar, majalah, tabloid, radio, tivi dan surat langsung.

Sigit (2007: 101) mengatakan bahwa Promosi adalah kegiatan perusahaan yang dilakukan untuk memberikan informasi, dan mengingatkan pihak lain mengenai perusahaan dengan produk dan jasa yang ditawarkan .

Untuk membina relasi terhadap pelanggan secara baik dan proefesional, pemilik usaha mesti merancang strategy promosi guna meningkatkan nilai planggan.

Keller (2008) mendefinisikannya sebagai tools yang digunakan dlaam usaha untuk memaklumkan, membujuk, serta mengingatkan (reminding) pengguna (secara langsung atau tidak langsung) mengenai produk dan jasa yang di jual.

Grewal dan Levy

(2008) mengatakan bahwa promosi adalah komunikasi yang dilakukan oleh pemilik produk atau jasa untuk berkomunikasi, membujuk, dan serta mengingatkan pembeli berpotensi produk untuk mempengaruhi pendapat pelanggan dan mendapatkan tanggapan dari pelanggan.

\section{Keputusan Pembelian}

Kotler dan Armstrong menyatakan bhwa di tahap evaaluasi, pelanggan akan meenentukan per- ingkat brand dan membentuk niàt pembeliian. Dengan kata lain adalah pelanggan membeli brand yang menurutnya paling ia sukai, akan tetapi beberapa faktor bisa beerada antara niat pmbelian dan kputusan pembelian.

Faktor pertama ditentukan berdsaarkan siikap orang lain. Jika ada seseorang yang berarti penting baginya, ia berpikir bahwa ia harus membeli produk yang paling murah, maka peluangnyaa 
untuk membeli produk yg lebih mahal berkurang.

Faktor lain diantaranya berasal dari situasiional ayng tak dihrapkan, dimana konsumen memiliki kmungkinan untuk mmbentuk niatbeli berdasarkan faktorfactor sperti gaji, haarga, serta beesar manfaat dari produk yang diharapkàn.

Kotler \&Armstrong (2012), menyatakan bahwa planggan adalah perilaku pembelian individu konsumen akhir dan atau rumah tangga yang membeli barang dan jasa untuk konsumsi pribadi.

Kotler \& Keller dalam Bob Sabran (2009), mengatakan bahwa Pelangggan akan melàlui 5 (lima) langkah dalam melakukan pembelian yaitu:

a. Pengenalan Masalah

Próses keputusanPembelian dimulai saat kustomer mengetahui kebutuhan atau dengan kata lain masalah. Kebutuhan tersebut dapat diputuskan oleh rangsangan internal atau eksternal. Rangsangan ini akan berubah menjadi dorongan. Berdasarkan dorongan yang ada pada diri konsumen maka konsumen akan mencari objek yang diketahui untuk dapat memuaskan dorongan tersebut.

b. Pencarian Informasi

Seorang pleanggan tergugah keinginannya hnyaa memiliki 2 (dua) kmungkinan yakni, aktif mncari informasi, atau mencaari informasi hanya untuk skedar tahu dan mnyimpannya dalam ingatan.

c. Evaluàsi Alternátif

Tidak ada proses evaluasi tunggal sederhana yang digunakan oleh semua konsumen atau oleh salah satu konsumen dalam semua situasi pembelian, itu berarti setiap konsumen pasti memiliki beberapa alternatif sebelum akhirnya menjatuhkan pilihan.

Beberapa konsep dasar dari proses evaluasi konsumen: Pertama, konsumen berusaha memenuhi kebutuhan; Kedua, konsumen mencari manfaat tertentu dari solusi produk; Ketiga, konsumen melihat masingmasing produk sebagai sekumpulan komponen dengan kelebihan yang berbeda-beda dalam menuai manfaat yang kemudian digunakan untuk memenuhi kebutuhan itu.

d. Keputusán Pembelián

Dalam langkah evaluasi, para pelanggan membuat preferensi atas brand-brand yang ada di dalam pilihan mereka. Konsumen tersebut juga bisa mencipta niat untuk membeli brand yang paling diminati. Juga terdapat 2 faktor yang dapat berada diiantara niat mmbeli dan kputusan membeli, yang pertama sikap orangg lain, yang memminimalisir arternatif 
Jurnal Semarak,Vol. 3,No.3, OKTOBER 2020, Hal (103-119)

@ Prodi Manajemen Fakultas Ekonomi Universitas Pamulang

yg disukai sesorang akan brgantung pada dua hal, yakni seberapa intens sikaap negatif oranglain terhdap pilihan yang di sukai, dan motivasi pelanggan utk mengikuti atau mnuruti keingiinan orang lain. Faktor lainnya, yang adalah fktor situasional yang tdak ter-antisipasi, bisa muncul dan karenanya mngubah niat pmbelian.

\section{E. Hipotesis Penelitian}

Hipotesis penelitian ini untuk menguji ada atau tidaknya pengaruh antara variabel independen (x) yaitu Kualitas Produk (x1) dan promosi (x2), terhadap keputusan pembelian sebagai variabel dependen (y). Adapun yang menjadi hipotesis nol (H0) dan hipotesis alternatif (Ha) dalam penelitian ini adalah sebagai berikut: :

1. Kualitas Produk (kualProd) terhadap keputusan pembelian (DB)

Ho1 : $\beta 1 \neq 0$ "tidak terdapat pengaruh kualProd terhadap DB yang signifikan"

Ha1 : $\beta 1=0$ "terdapat pengaruh kualProd terhadap DB yang signifikan"

2. Promosi terhadap keputusan pembelian

Ho2 : $\beta 1 \neq 0$ "tidak terdapat pengaruh yang signifikan antara Promosi terhadap Keputusan Pembelian"
$\mathrm{Ha} 2: \beta 1=0$ "terdapat pengaruh yang signifikan antara Promosi terhadap Keputusan Pembelian"

3. Kualitas Produk dan Promosi terhadap keputusan pembelian

Ho3 : $\beta 1 \neq 0$ "tidak terdapat pengaruh yang signifikan antara Kualitas Produk dan Promosi terhadap Keputusan Pembelian"

Ha3 : $\beta 1=0$ "terdapat pengaruh yang signifikan antara Kualitas Produk dan Promosi terhadap Keputusan Pembelian"

\section{METODE PENELITIAN}

Tempat penelitian ini dilakukan yakni BSD Green Office Park 9, Sayap B lantai 1, Tangerang Kota/Kab. Tanggerang. Penelitian ini menggunakan metode kuantitattif. Sugiono(2009) mengatakan bahwa penelitian kuan titatif dipakai untuk meneliti suatu kumpulan objek atau subjek atau sampel yang telah ditentukan sebelumnya, secara umum, pengambilan sample mengugnakan teknik pengambilan scara acak atau random, yang kemudian dengan memanfaatkan instrumentasi penelitian berupa point point pernyataan kuesioner dan analisa data kuantitatif, memiliki tujuan untuk menguji hipotesis atau dugaan semnetara yang telah dirumuskan sebeelumnya. 


\begin{abstract}
Menurut Kuncoro (2009),
Riset dekriptif digunakan untuk membuat gambaran terhadap karakteristik responnden, melihat pada bentuk penelitian ini, tipe kausal adalah penelitian yang mengukuur kekuatan hbungan antara dua atau lebih variable, juga penentuan arah hubungan antara variable bebas dengan variable.terikat.
\end{abstract} Berguna untuk menganalisis hubungan hubungan yang saling mempengaruhi.

Populasi yang digunakan peneliti saat melakukan penelitian yakni customer GeneralTrade pareto diwilayah Jabodetabek sebanyak 130 customer autlet yang melakukan pembelian produk air minum pristine scara brkala di PT.Super Wahana Tehno.

Dalam penelitian ini seluruh subjek atau objek diteliti sehingga dapat disebut sebagai sampell jenuh. Yang menurut Sugiono (2012) Sample Jenuh adalah teknik yang mnjadikan seluruh anggota populasi mnjadi anggota saample.

Sample dalam penelitian yakni para customeer GneeralTrade (GT) area Jabodetabek yg membeli produk air minum Pristine $8+$ seccaara terus menerus dalam tenggat waktu tertentu.

$$
\text { Caraanya adalah melalui }
$$
pendistribusian angket scra langgsung kepada para peserta survey. Disebarkan quiz survey scra kseluruhan se banyak 130 angket, sehingga quiz yang kembali dengan lengkap kepada peneliti sebanyak 113 jwaban pserta survey, kemudiian, data ini menjadi data penelitian. Nama lain dari sampling jenuh adalah sensus, yakni menjadikan keseluruhan anggota populasi sebagai sampling. Peneliti dalam hal ini berpendapat bahwa sensus akan mengukur lebih akurat mengingat data penelitian dengan jumlah responden tersebut diatas.

Metode pengambilan sampel dari penelitian ini adalah non probability sampling, yakni pengambilan sampel yang tekniknya tidak memberi peluang atau kesempatan sama bagi setiap anggota populasi untuk dipilih menjadi sampel (Sugiyono, 2009). Metode yang digunakan dalam pengumpulan data ini adalah survai, menggunakan kuesioner sebagai alat pengumpulan datanya.

Secondary data, pengumpulan data diilakukan dengan study literature dan pencarian data di journal yang meneliti tema yang sejeniis. Jenis Pernyataan yang tertera dalam kuesioner adalah “Structure Non Disguised" yakni jenis pernyataan yang merupakan multiple Page | 110 
choices yang berpedoman kepada likert scale yang digunakan untuk mengukur sikap, pendapat, dan persepsi bagi seorang responden. Bentuk penilaian jawaban kuesioner menggunakan pembobotan 5 buah skala (Sugiyono, 2009).

\section{HASIL DAN PEMBAHASAN}

\section{A. Gambaran Objek Penelitian}

Bizzy Distribution yang secara legal berada dibawah PT.SDN (Sinarmas Distribusi Nusantara) adalah perusahaan distributor nasional dengan pengalaman lebih dari 25 tahun di industri Fast Moving Consumer Goods (FMCG) di Indonesia. Dengan memiliki 26 cabang dan 100 subdist yang tersebar di seluruh Indonesia, SDN telah melayani prroses penjualan dan disstribusi produk-produk konsumen dari merek Fast Moving Consumer Goods (FMCG) terkenal ke seluruh pasar traditional, pasar moderen, toko grosir dan industri layanan makanan hingga 200.000 titik distribusi. (tentang, bizzy.co.id/bizzydistribution, akses 3 augstus 2020)

PT SUPER WAHANA TEHNO didirikan di bulan Maret tahun 2000, dibawah PT. Sinar Mas Multiartha, salah satu grup investasi terbesar di Indonesia. Di tahun 2005, PT SUPER WAHANA
TEHNO mulai melayani di industri yang berhubungan dengan kesehatan.

Berletak di jalan BSD Grand Boulevard, BSD City - Tanggerang 15345, Indonesia, gedung GOP9 - sayap B.

Berawal dari sebagai agen eksklusif untuk produk kesehatan di seluruh Indonesia, dengan merek SIMBIO, PT.Super Wahana Tehno, yang juga salah satu anak perusahaan SINARMAS Group,saat ini telah bekerjasama dengan salah satu perusahaan Jepang bernama Nihon Trim.Co.Ltd. Dengan teknologi dan di bawah pengawasan dari Nihon Trim Co.Ltd., sejak November 2006, PT.Super Wahana Tehno telah memproduksi dan meluncurkan produk baru yaitu air mineral ionisasi, untuk yang pertama kali dan satusatunya di Indonesia dengan merk PRISTINE. (Profile Perusahaan 2018. http://superwahanatehno.com/bahasa/com panyfeature.html, diakses 05 Agustus 2020)

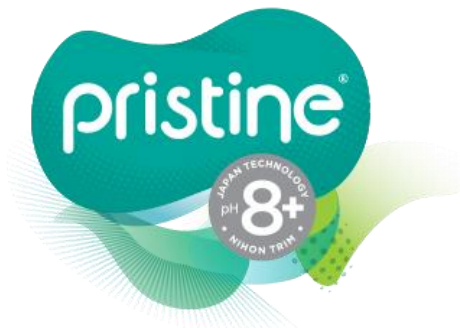

Gambar 1. Logo Pristine 8+ MISI PERUSAHAAN 
Produk Pristine sendiri sudah tersedia untuk para pelanggannya di kawasan rumah tangga maupun pelanggan di wilayah perkantoran. Berikut dibawah ini adalah varian produk Pristine air mineral:

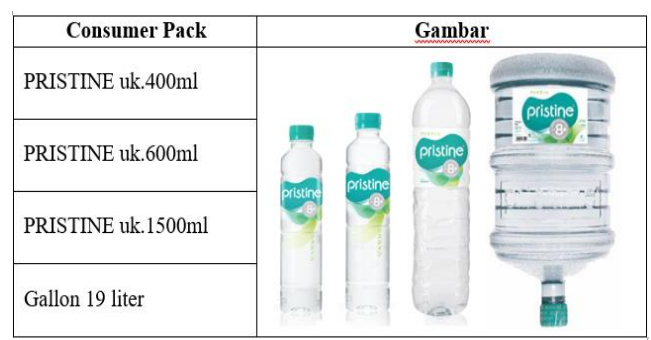

Table 1. Varian Produk Pristine

\section{B. Penemuan dan Pembahasan}

\section{Validity dan Reliability Test}

Berdasar pada teori Grondlund (Ibrahim \& Wahyuni, 2012) valiiditas merujuk pada akurasi penggambaran dampak pemakaian suatu instrumentasi untuk mengevaluasi pengukuran sesuai dengan tujuannya. Valid adalah suatu kondisi dimana suatu instrument ukur dapat mengukur sebenar-benarnya dan tepat. Menurut Surapranata (2004), instrument pengukur dikatakan valid jika benar-benar dapat memproyeksikan hasil perhitungan ilmu hitung. Validiitas alat ukur bukan hanya berhubungan dngan keduudukan alat pengukur sbagai instrumentasi, tapi juga pada kesesuaian dari hasilnya, apakah sesuai dengan tjuan pnyelenggaraan alat ukur.

Formula Hubungan ProductMoment:

$$
r_{x y}=\frac{N \Sigma x y_{-\left(\sum x\right)}\left(\sum y\right)}{\sqrt{\left(N \Sigma x^{2}-\left(\sum x\right)^{2}\left(N \Sigma y^{2}-(\Sigma y)^{2)}\right.\right.}}
$$

Note:

$$
\begin{aligned}
& r_{x y}=\text { Koefisien korelasi antara variabel } \mathrm{X} \text { dan variabel } \mathrm{Y} \\
& \sum x \mathrm{y}=\text { Jumlah perkalian antara variabel } \mathrm{x} \text { dan } \mathrm{Y} \\
& \sum x^{2}=\text { Jumlah dari kuadrat nilai } \mathrm{X} \\
& \sum y^{2}=\text { Jumlah dari kuadrat nilai } \mathrm{Y} \\
& \left(\sum x\right)^{2}=\text { Jumlah nilai X kemudian dikuadratkan } \\
& \left(\sum y\right)^{2}=\text { Jumlah nilai } \mathrm{Y} \text { kemudian dikuadratkan }
\end{aligned}
$$

Hasil Uji Validitas

\begin{tabular}{|c|c|c|c|c|}
\hline \multicolumn{5}{|c|}{ Hasil Uji Validitas Product Quality } \\
\hline No & Poin Quiz & $\begin{array}{c}\text { Nilai } \\
\text { hitung }\end{array}$ & $\begin{array}{c}\text { Nilai r } \\
\text { tabel }\end{array}$ & Result \\
\hline 1 & KP1 & 0,684 & 0,1832 & VALID \\
\hline 2 & KP2 & 0,700 & 0,1832 & VALID \\
\hline 3 & KP3 & 0,682 & 0,1832 & VALID \\
\hline 4 & KP4 & 0,753 & 0,1832 & VALID \\
\hline 5 & KP5 & 0,779 & 0,1832 & VALID \\
\hline 6 & KP6 & 0,651 & 0,1832 & VALID \\
\hline 7 & KP7 & 0,651 & 0,1832 & VALID \\
\hline 8 & KP8 & 0,753 & 0,1832 & VALID \\
\hline 9 & KP9 & 0,779 & 0,1832 & VALID \\
\hline 10 & KP10 & 0,651 & 0,1832 & VALID \\
\hline \multicolumn{5}{|c|}{ Promotion } \\
\hline 1 & P1 & 0,684 & 0,1832 & VALID \\
\hline 2 & P2 & 0,768 & 0,1832 & VALID \\
\hline 3 & P3 & 0,760 & 0,1832 & VALID \\
\hline 4 & P4 & 0,327 & 0,1832 & VALID \\
\hline 5 & P5 & 0,368 & 0,1832 & VALID \\
\hline 6 & P6 & 0,526 & 0,1832 & VALID \\
\hline \multicolumn{5}{|c|}{ Buying Decision } \\
\hline 1 & BD1 & 0,745 & 0,1832 & VALID \\
\hline 2 & BD2 & 0,741 & 0,1832 & VALID \\
\hline 3 & BD3 & 0,673 & 0,1832 & VALID \\
\hline 4 & BD4 & 0,712 & 0,1832 & VALID \\
\hline 5 & BD5 & 0,694 & 0,1832 & VALID \\
\hline 6 & BD6 & 0,656 & 0,1832 & VALID \\
\hline 7 & BD7 & 0,687 & 0,1832 & VALID \\
\hline
\end{tabular}

Table 2. Hasil Validitas Uji 
Selaras dengan pernyataan Sugiyono (2013) dalam bukunya yang mengatakan bahwa Hasil perhitungan uji validitas sebagaimana table hasil validitas sebelumnya menunjukkan bahwasanya seluruh scoring $\mathrm{r}_{\text {hitung }}$ lebih besar dari nilai $\mathrm{r}_{\text {Table }}(0,1832)$. Karenanya, dapat diambil ksimpulan bhwa prnyataan dalam survey ini validd dan dapat digunakan sbagaai instrumentasi penelitian.

\section{Pengujian Relia bilitas}

Ferdinand (2006) mengatakan bahwa Uji Relia bilitas adalah uji yang dipakai untuk memproyeksikan oinstrumentasi survey yang merupakan indikator dari suatu variabel. Sebuah instrumen dan data yang dihasilkan disebut reliable atau terpercaya apabila instrumen tersebut secara konsisten memunculkan hasil yang sama setiap kali dilakukan pengukuran. Adapun cara yang digunakan untuk menguji reliabiltas kuesioner dalam penelitian ini adalah menggunakan rumus koefisien Alpha Cronbach, yaitu:

1. Jika nilai koef alpha cronbach lebih besar dai taraf signifikansi 0,6 atau $60 \%$, instrument bersifat reliabel, dan

2. Jika nilai koef alpha cronbach lebih kecil dari taraf signifikansi 0,6 atau $60 \%$, instrument bersifat tidak reliabel.

\begin{tabular}{|c|c|c|c|}
\hline Variabel & $\begin{array}{c}\text { Cronbach's } \\
\text { Alpha }\end{array}$ & N of Items & $\begin{array}{c}\text { Kategori Interval } \\
\text { Reliabilitas }\end{array}$ \\
\hline Kualitas Produk $\left(\mathrm{X}_{1}\right)$ & $\mathbf{0 , 8 7 2}$ & 10 & Reliabel \\
\hline Promosi $\left(\mathrm{X}_{2}\right)$ & $\mathbf{0 , 8 2 1}$ & 6 & Reliabel \\
\hline Keputusan Pembelian $(\mathrm{Y})$ & $\mathbf{0 , 8 1 0}$ & 7 & Reliabel \\
\hline
\end{tabular}

Table 3. Hasil Reliabilitas Uji

Dari hasil Reliability test diperoleh nilai Cronbach alpha semua variabel > 0,600 . Hal ini sesuai dengan Sugiyono (2013) dalam bahasannya, dimana semua nilai Cronbach Alpha yang terhitung > 0,60 dan aartinya semua data bersifat reliable, Karenanya, dapat di simpulkan bhwa setiap pernyataan dalam quiz ajeg atau reliable serta consistent, srta dapat di gunakan sebaagai instrumentasi penelitian.

\section{Test Classic'sAssuption}

a. Normality Test

Penguujian normalitas dilakukan dengan mlakukan uji terhadap nilai sisa atau residue score, sedang, testing dilakukan dengan menggunakan graffik p-plot dan kolmogrov smiirnov test.. Basis pengammbilan keputusan dlam Normality test yaitu:

1. Jika Asymp.sig score lebih besar $5 \%$, maka data berdistribusi normal

2. Jika Asymp.sig score lebih besar $5 \%$, maka data tidak berdistribusi normal. 
Pada pengujian normalitas ini dapat dilihat dari Table di bawah ini:

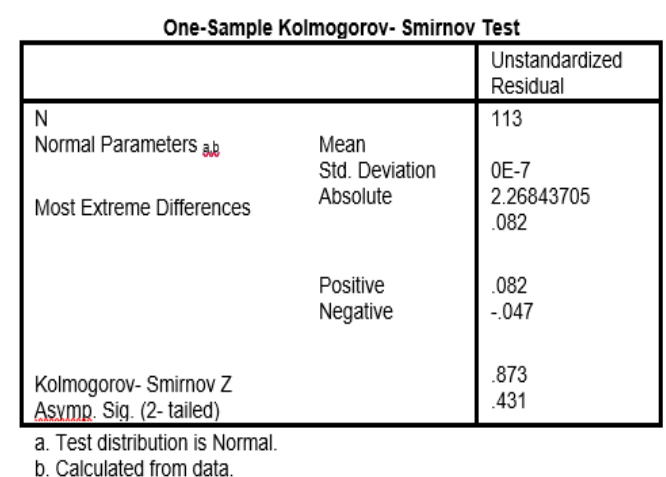

\section{Table 4 Hasil Uji Normalitas}

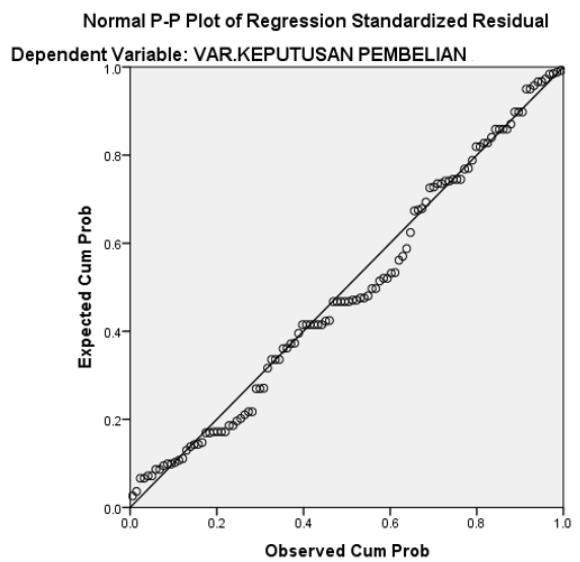

Gambar 2. Plot $P$

Melihat gambar histogram p-plot tersebut menunjukan bahwa data penelitian dalam model regresi terdistribusi normal. Hal tersebut di gambar terlihat bhwa titik titik plot mengikuti garis diagonal.

Artinya bahwa penyebaran data terdistribusi disekitar garis diagonal (tidak terpencar jauh dari garis), dapat dikatakan memenuhi gejala normalitas secara syarat terpenuhi. Peneliti dapat mengambil ksimpulan pengujian model regresi dapat digunakan untuk pengujian-pengujian selanjutnya.

\section{b. Multikolinieritas Test Pengujian Multiko- linieritas mendasari pengambilan kputusannya dengan beberapa point berikut:}

\section{Tolerance Score}

a. Multiklonieritas tiidak akan ada, apabila tolerance score kurang dari 0,10 .

b. Multiklonieritas ada apabila tolerance score $\leq 0,10$.

2. Berdasarkan pada variasi faktor inflasi atau VIF

a. Multiklonieritas tidak akan ada, jika tolerance score < 10,00 .

b. Multiklonieritas ada jika tolerance score $\geq 0,10$.

Pengujian multi kolinieritas mengunakan analisis yang dibantu program aplikasi SPSS versi 23.0, dengan ringkasan hasil uji multi sebagai berikut.

\begin{tabular}{|c|c|c|}
\hline Model & Tolerance & VIF \\
\hline Kualitas Produk & $0,805>0,10$ & $1,242<10,0$ \\
\hline Promosii & $0,805>0,10$ & $1,242<10,0$ \\
\hline
\end{tabular}

Table 5 Hasil Uji Multi kolinier

Melihat ringkasan hasil uji multi kolinie ritas diatas, nilai tolerance yang berada dibawah 0,1 serta nilai variasi faktor inflasi 
yang kurang dari 10, dapat peneliti simpulkan bahwa tidak terdapat gejala-gejala multi kolinieritas.

\section{Pengaruh Secara Partial}

Menguji pengaruh masing-masing variable brdasarkan perbandiingan $t_{\text {hitung }}$ masing masing koef.reg dgn $t_{\text {Table }}$ di taraf signifikansi 0,05 . Membaca perhitungan angka dengan program apps SPSS ver23 diperoleh t-hitung bagi independence variable differenciation competitive, variable $\mathrm{X}_{1}$ atau ProdQual trhadap dependence variable $\mathrm{Y}$ (BuyingDecision), dapat diliihat dalam Table sebagai berikut:

\begin{tabular}{|c|r|r|r|r|r|}
\hline \multirow{2}{*}{ Model } & \multicolumn{2}{|c|}{$\begin{array}{c}\text { Unstandardized } \\
\text { Coefficients }\end{array}$} & $\begin{array}{c}\text { Standardized } \\
\text { Coefficients }\end{array}$ & \multirow{2}{*}{ Sig. } & \\
\cline { 2 - 4 } & \multicolumn{1}{|c|}{ B } & Std. Error & Beta & & \\
\hline (Constant) & 15.237 & 2.221 & & 6.421 & .000 \\
1 Kualitas Prod & .324 & .075 & .387 & 2.337 & .000 \\
Rromosi & .304 & .106 & .256 & 4.876 & .005 \\
\hline
\end{tabular}
a. Dependent VariableBuying Decision

\section{Table 6 Hasil Uji Partial t}

\section{Pengujian Hipotesis I}

$\mathrm{Ho}_{1}: \beta 1 \neq 0 \quad$ "tidak terdapat pengaruh yang signifikan dari Kualitas Produk terhadap keputusan pembelian"

$\mathrm{Ha}_{1}: \beta 1=0 \quad$ "terdapat pengaruh yang signifikan dari Kualitas Produk terhadap keputusan pembelian"

Memperhatiakan table tersbut dapat disimpulkan bahwa variabel ProdQual diperoleh signifikansi $t_{\text {hitung }}$ lebih kecil dari $\mathrm{t}_{\text {Table }} 0,05(0,000<0,05)$ dan $\mathrm{t}$ hitung 2,337 > Table sebesar 1, 659 maka artinya H01 rejected dan Ha1 approved, artinya ada pengaruh signifikan antara variable $\mathrm{X} 1$ ProdQual dengan BuyingDecision (Y).

\section{Pengujian Hipotesis II}

$\mathrm{HO}_{2}: \beta 2 \neq 0$ "tidak terdapat pengaruh yang signifikan dari promosi terhadap keputusan pembelian"

$\mathrm{Ha}_{2}: \beta 2=0$ "terdapat pengaruh yang signifikan dari promosi terhadap keputusan pembelian"

Dari Table 6 mengenai uji partial sebelumnya, dapat diambil kesimpulan bahwasanya signifikansi Promosi (t) hasilnya lebih besar dari 0,005 $(0,005<0,05)$ dan $t$ hitung 4,876 > tTable sebesar 1,659 (4,876> 1,659) atau berarti $\mathrm{HO}_{2}$ ditolak dan $\mathrm{Ha}_{2}$ diterima, hal ini menunjukan bahwa terdapat pengaruh yang signifikan dari promosi terhadap keputusan pembelian.

\section{Pengaruh Secara Bersamaan} (Simultanous)

a. Pengaruh ProdQual dan Promosi Terhadap KeputusanPembelian

Ho3 : $\beta 1 \neq \beta 2 \neq 0 \quad$ X1 (Kualitas Produk) \& X2 (Promosi) tiidak brpengaruh signifikan terhadap $\mathrm{Y}$ (KeputusanPembelian).

Ha3 : $\beta 1=\beta 2=0 \quad X_{1}$ dan $X_{2}$ berpengaruh signifikan terhadap $\mathrm{Y}$. 
Berdasarkan pengjuian anova pada Table dibawah ini nilai signi-fikan 0,000 lebih kecil daripada nilai signifikansi 0,05 dan nilai $\mathrm{F}_{\text {hitung }} 21,355$ lebih besar drpd nilai $\mathrm{F}_{\text {Table }}$ yaitu 2, 690 yang berarti H03 ditolak dan Ha1 diterima, yang artinya, kedua variable dependence berpengaruh secara bersama-sama terhadap variable independence nya.

Hasil pengujian uji $\mathrm{F}$ yang diolah menggunakan aplikasi statistic SPSS dapat dilihat detailnya pada table dbi:

\begin{tabular}{|c|c|c|c|c|c|c|}
\hline \multicolumn{7}{|c|}{ ANOVA $^{a}$} \\
\hline Model & & Sum of Square & $\mathrm{df}$ & Mean Square & $\mathrm{F}$ & Sig. \\
\hline & Regression & 247.815 & 2 & 123.908 & 21.355 & $.000^{\circ}$ \\
\hline 1 & Residual & 571.185 & 111 & 5.240 & & \\
\hline & Total & $819.00 \mathrm{~d}$ & 113 & & & \\
\hline
\end{tabular}

a. Dependent Variable: VAR. Keputusan Pembelian

b. Predictors: (Constant), VAR.Kualitas Prod., VAR. Promosi

\section{Table 7 Hasil Uji Simultan F}

Berdasarkan hasil analisis pengaruh secara simultan atau bersama-sama variabel kualitas produk dan promosi terhadap keputusan pembelian diperoleh pengaruh positif dan signifikan dengan persamaan regresi $\mathrm{Y}=$ $15,237+0,324 \mathrm{X}_{1}+0,304 \mathrm{X}_{2}$ dengan kontribusi sebesar $15,23 \%$ sedangkan sisanya sebesar $84,77 \%$ dipengaruhi oleh faktor lain. Dari pengujian hipotesis menunjukkan bahwa nilai $F_{\text {hitung }}$ lebih besar dari FTable atau $(21,355$ > 2,81). Maka Ho ditolak dan Ha diterima.

\section{Koeffisien Determ inasi}

Koeffisiensi determiinasi didapatkan caranya dengan mengkuadratkan correlate result dan dikalikan dengan $100 \%$.

\begin{tabular}{|l|r|r|r|r|}
\hline Model & \multicolumn{1}{|c|}{ Model Summary } \\
\hline 1 & R Square & $\begin{array}{c}\text { Adjusted R } \\
\text { Square }\end{array}$ & $\begin{array}{c}\text { Std. Error of the } \\
\text { Estimate }\end{array}$ \\
\hline
\end{tabular}
a. Predictors: (Constant), VAR.Kualitas Prod, VAR.Promosi
b. Dependent Variable: VAR.Keputusan Pembelian

\section{Table 8 Koef Determ inasi}

Diliaht dari hasil pengujian menggunakan aplikasi SPSS23, hasil koef determ inasi atau r-kuadrat $\left(r^{2}\right)$ yakni 0,304. Angka tersebut menunjukan besarnya sumbangsih relative dari gabungan dua variable dependen terhadap variable KeputusanPembelian (y) adalah sebesar $30,4 \%$, yang artinya $69,6 \%$ dipengaruhi oleh variabel lain diluar penelitian.

\section{KESIMPULAN\&SARAN}

\section{A. Kesimpulan}

Berikut Point-point yang dapat peneliti simpulkan berdasar pada analisis ayng dilakukan sebeluumnya:

1. Kualitas Produk (KP) brpengaruh positive and significant terhadap Keputusan Pembelian Produk Air Minum Pristine, hal ini ditunjukan dari nilai signifikansi nol atau lebih kecil daripda nilai signifikansi 5\% dan $t_{\text {hitung }}>t_{T a b l e}$, nilai koef.regresi 
KP positive, yaitu 0,324 , menunjukkan tiap penambahan KP sebesar satu satuan akan meningkatkan keputusan pembelian Produk Air Minum Pristine sebesar $32,4 \%$

2. Promosi brpngaruh positive and significant terhadap Kepu-tusan Pembeliian Air Minum Pristine signifikansi score $=0$ atau lebih kecil daripda nilai signifikansi $5 \%$ dan $\mathrm{t}_{\text {hitung }}$ $>\mathrm{t}_{\text {Table }}$ dikatakan pengaruhnya posritif krna nilai positif dari koefisienn regresinya yang bernilai positif, di angka 0,304 yang dimana angka ini berarti setiap pertambahan kualitas poduk sebesar 1 satuan maka akan meningkatkan nilai Keputusan Pembelian Produk Air Minum Pristine senilai 0,304 atau $30,4 \%$

3. KualitasProduk (X1) dan Promosi (X2), brpengaruh positive and significant scara bersama-sama terhaadap KeputusanPembelian (Y) karena nilai signifikansi nol atau lebih kecil daripda nilai signifikansi 5\% dan $\mathrm{t}_{\text {hitung }}>\mathrm{t}_{\text {Table }}$ dan nilai $\mathrm{F}$ hitung $(21,355)$ $>$ nilai $\mathrm{F}$ Table $(2,69)$ dngan nilai besaran pengaruuh Kualitas Produk (X1) dan Promosi (X2) terhadap Keputusan Pembelian Keputusan
Pembelian Produk Air Minum Pristine sebesar $23,6 \%$

4. Hasil perhitungan Koefisien Determinasi bahwa sumbangan relatif yang diberikan oleh kombinasi variabel kulitas Kualitas Produk (x1) dan Promosi (x2) terhadap Keputusan Pembelian (y) adalah sebesar $30,4 \%$ sedangkan sisanya sebesar $69,6 \%$ dipengaruhi oleh variabel lain yang tidak di teliti.

\section{B. Saran}

Berdasarkan kepada hasil penelitian, berikut point-point saran yang perlu disampaikan kepada objek penelitian yakni PT Super Wahana Tehno., serta untuk keperluan penelitian slanjutnya, sbb:

1. Untuk PT Super Wahana Tehno, sebagai Óbjek yang diteliti, Melihat hasil analsisis, Var. Kualitas Produk pada pernyataan Kualitas Produk air minum pristine sebagai plihan utama mendapat score terendah. Hal ini dikarenakan kurangnya edukasi kepada masyarakat tentang pentingnya kandungan dalam air minum, tingginya kadar $\mathrm{pH}>8$ pada air minum Pristine sehingga cenderung memiliki rasa pahit, mempengaruhi kualitas air minum bagi konsumen, jika dibandingkan dengan merek air minum dalam kemasan yang sejenis.

Page | 117 
2. Bagi Peneliti selanjutnya

$$
\text { Peneliti selanjutnya dapat }
$$
membuat jenis penelitian yang lebih dikembangkan melalui cara atau metode lain, misalnya melalui wawancara, studi lapangan, jenis penelitian kualitatif dan lainnya sehingga info rmasi yang diperroleh dpat lebih bervariiasi dripada survey yang jawabanya telah di set sebelmnya..

\section{DAFTAR PUSTAKA}

Arikunto, Suharsimi. 2010. "Prosedur Penelitian Suatu Pendekatan Praktek". PT. Rineka Cipta. Jakarta.

Buchari Alma, 2007, Manajemen Pemasaran dan Pemasaran Jasa, Alfabeta, Bandung

Fandy Tjiptono, 2008. "Strategi Pemasaran”. Yogyakarta.:Andi.

Ghozali, Imam. 2005, "Aplikasi Analisis Multivariate dengan Program SPSS", Semarang: BP Undip Semarang.

Haryoko, U. B., Pasaribu, V. L. D., \& Ardiyansyah, A. (2020). PENGARUH HARGA DAN KUALITAS PELAYANAN TERHADAP KEPUASAN KONSUMEN PADA FIRMAN DEKORASI (WEDDING ORGANIZER). POINT, 2(1).

Irfanudin, Ahmad Maulana. 2020. "Manajemen Pemasaran, Konsep dasar dan Strategi”. CV. AA. RIZKY. Banten.
Jeffrey K. Liker, Michael Hoseus 2008 Toyota Culture : Jantung dan Jiwa Toyota, Toyota Way, Erlangga

Kotler, Philip dan Kevin Lane Keller, “Manajemen Pemasaran", Edisi 13, Jilid 2, Erlangga, Jakarta. 2013.

Kotler, Philip, \& Keller, Kevin L, "Manajemen Pemasaran", Edisi 13 jilid 1, Erlangga, Jakarta, 2009.

Kotler, Philip dan Amstrong, Gary, (2013), Principles of Marketing, 12th Edition, Jilid 1 Terjemahan Bob Sabran, Jakarta : Erlangga.

Rangkuti, Freddy. 2016. "Riset Pemasaran". PT. Gramedia Pustaka Utama, Jakarta.

Lewis, Pamela S. Stephen H. Goodman, Patricia M. Fondt, 2004, Management; Challenges For Tomorrow's Leader", McGraw Hill

Nasution, M.N, 2004, Manajemen Jasa Terpadu, PT. Ghalia Indonesia, Jakarta

Pasaribu, V. L. D. (2020). ANALISIS PENGARUH PROMOSI, KUALITAS PRODUK DAN DESAIN KEMASAN TERHADAP KEPUTUSAN PEMBELIAN HAND AND BODY LOTION MEREK CITRA (Studi Kasus Carrefour Pamulang, Tangerang Selatan). Jurnal Pemasaran Kompetitif, 1(4).

PASARIBU, V. L. D. (2017). ANALISIS PENGARUH PROMOSI, KUALITAS PRODUK DAN DESAIN KEMASAN TERHADAP PERSEPSI MEREK YANG 

BERDAMPAK
KEPADA
KEPUTUSAN PEMBELIAN HAND
AND BODY LOTION MEREK
VASELINE (Studi Kasus TIP TOP
Ciputat,
Selatan). INOVASI, 4(2).

Pasaribu, V. L. D., \& Prayoga, M. Y. S. (2019). Pengaruh Kualitas Produk Baju Batik Hem Terhadap Kepuasan Pelanggan Pada Home Industri Batik Sahara Indah. Jurnal Pemasaran Kompetitif, 2(2), 77-83.

Pasaribu, V. L. D. PENGARUH STORE ATMOSPHERE TERHADAP KEPUTUSAN PEMBELIAN PADA RESTORAN DE'COST GIANT PAMULANG SQUARE TANGERANG

SELATAN. Manajerial: Jurnal Manaiemen dan Sistem Informasi, 19(2), 156-167.

Rambat Lupiyoadi dan A. Hamdani 2008, Manajemen Pemasaran Jasa, Salemba Empat, Jakarta

Riduwan, 2010, Metode dan Teknik Menyusun Tesis, Alfabeta Bandung

Sugiono,2012, "Metode Penelitian Kuantitatif Kualitatif dan $R \& D$ ", Penerbit CV. Alfabeta.Bandung.

Tjiptono, Fandy, 2008, Bauran Pemasaran Jasa, bayu Media, Jawa Timur

Tjiptono, Fandy. 2002. Manajemen jasa, Edisi II, Cetakan ketiga. Andi Offset. Yogyakarta.

Tjiptono, Fandy dan Gregorious Candra. 2005. Service, Quality, and Satisfaction. Andi Offset. Yogyakarta.

Vanessa, Gaffar. 2013. Customer Relationship Management and Marketing Public Relation. Alfabeta. Bandung 